\title{
IOWA PIONEER LAWMAKERS ASSOCIATION
}

Twenty-eighth Biennial Meeting in JoInt Session With Fifteth Iowa General Assembly

\section{By ORA WILliams, Secretary}

A special committee of the Joint Convention of the Fiftieth General Assembly in session in the chamber of the House of Representatives, Wednesday afternoon, February 24, 1943, escorted members of the Iowa Pioneers Lawmakers Association to seats at the front of the house chamber and Pres. Ray P. Scott with others on the program to the speaker's stand. The committee was appointed by President Blue and consisted of Senator Findlay of Webster county, on the part of the senate, and Representatives McFarlane of Blackhawk and Wamstad of Mitchell counties on the part of the house.

President Blue announced the program for the afternoon, which proceeded with special music by the Songfellows Quartet, by courtesy of WHO radio broadcasting station. He then presented President Scott of the Pioneer Lawmakers, who presided and extended a brief greeting to the legislators assembled, saying:

"Once again we are very grateful to the General Assembly of Iowa for the resolution inviting us to return to the scenes of former labors and spend a day here at the capitol with you. Our numbers are somewhat depleted because of the difficulty in transportation and travel, but we have a goodly number present and have had a delightful time this morning and this noon. We are very happy at this time to have a word of welcome from the very capable Speaker of the House, the Honorable Henry W. Burma."

SPEAKER BURMA: "Pioneer Lawmakers of Iowa, the Fiftieth General Assembly of Iowa greets you and extends to you a warm welcome. Your presence here is evidence that though you are not now members of this As- 
sembly, you are still interested in the affairs of government and we of the Fiftieth General Assembly are grateful to you for the fine service you rendered in years gone by as lawmakers of Iowa. During the sessions that I have sat here in the chamber, when you gentlemen came in I looked upon you with respect and admiration, and more so now when the stability of our American institutions and our American homes is threatened. We need more than ever before the pioneer courage, the pioneer spirit, and the pioneer conception of loyalty, of honor, and of justice.

"You have rendered a valuable service. You were the trailblazers for us, so to speak. We regard your efforts and your work very highly: We are indeed happy to have you here this afternoon and, as one eminent person once said, 'We will think very much of you, and will think of you very much.' I thank you for coming here and we want you to know that the Fiftieth General Assembly deeply and warmly welcomes you."

\section{OUR Military TASK}

PResident ScotT: "The United States of America has embarked upon the most stupendous military program in its history, and I think it is perfectly fitting that we in Iowa should pause a moment and take some thought of that program. The next speaker this afternoon, a former member of the state senate of Iowa, is one who served with distinction in the first World War. In fact, I am told by some of the men that served under him that they regarded him as one of the bravest men that they had ever known or seen. And it is my very great pleasure at this time to present to you the Honorable Claude M. Stanley, who will speak to the subject "Our Military Task."

Colonel Stanley's address to: the Assembly follows:

My fellow Americans: I am happy to be here today to participate in your program. I would be much more happy if I were participating in the great program of our country to which your 
president has just referred. I am in somewhat of a peculiar situation in that I am out of the senate and have not been out long enough to be eligible to be a member of the Pioneers.

In addressing the General Assembly of Iowa, as one having been a former member thereof, I have a feeling that $I$ am to some extent in the position of the former president of a business men's club at the inauguration of his successor. After the installing official had inducted. the newly elected president into office, had taken the gavel from the outgoing officer and had presented it to the newly installed officer, he turned to the retiring president and said: "It is my painful duty to pin on you this badge of a past president of this organization. In the performance of your service you have been diligent and faithful and your suggestions and advice have been well received. There are fifteen past presidents in this organization. We welcome you in. But soon you will learn, as each one of us has learned, that you are in somewhat the position of a mother-in-law. She suggests many ideas and offers much information and advice, and little heed is taken."

In discussing our present military task it is my desire to call to your attention some of the services that have been and are being rendered by the men and women of Iowa in the military field.

Iowa was created as a territory in the year 1838, and since that time our state has on every occasion where military service was required done her full share and even more than her full share, by having furnished a higher percentage of her population to the armed forces than was furnished by many other states. Governor Robert Lucas in his first message to the Legislative Assembly in 1838 advocated an efficient and disciplined militia for the territory, and caused legislation to be set in motion to accomplish that result.

The first occasion on which military service was performed was with respect to the dispute over the boundary line between the state of Missouri and the state of Iowa. That was known as the Iowa-Missouri War. At that time Iowa was a territory. That was in 1839 and was the beginning of a long list of distinguished services performed by Iowa citizens in the military field.

In 1846 when the call came for soldiers to enlist for service in the war with Mexico the militia organization of the Territory of Iowa was practically nonexistent, but Iowa furnished for that service a regiment consisting of ten companies.

In 1857 Iowa men participated in defending the state against the invasion by a hostile band of Sioux Indians during which the Spirit Lake Massacre occurred.

In the war between the states known as the Civil War, Iowa furnished a total of 76,242 men. These men participated in many of the campaigns and battles against the Confederate Army. Of 
these, 13,001 lost their lives either as battle casualties or through the ravages of disease. The records are full of the valiant deeds of individuals and of the organizations on many fields of battle.

When war was declared against Spain in 1898 President McKinley issued a call for 125,000 volunteers. On April 25 of that year the governor of Iowa ordered all four regiments of the Iowa National Guard into action. These regiments saw service in Jacksonville, Florida, and Chickamauga Park, Georgia, and one regiment, the Fifty-first Iowa, saw service at San Francisco, California, and in the Philippine Islands, and participated in many campaigns incident to the Philippine Insurrection. For the Spanish American War Iowa furnished 5,859 officers and enlisted men through the National Guard organization.

In 1916 when there was serious threat of trouble on the Mexican border Iowa sent three organizations of infantry, a battalion of artillery, and squadron of cavalry to the southern border of the United States where the troops remained until early in 1917 when they were returned home.

For the first World War Iowa furnished 114,218 men which included the entire personnel of the national guard recruited to war strength. In the organization of the Forty-second Division, known as the Rainbow Division, Iowa furnished an infantry regiment which was designated as the 168th Infantry. In order that this regiment might be brought to full war strength detachments were taken from the other regiments of the national guard, and it may be said that this regiment was representative of the entire state. Other Iowa men went into this service through conscription or volunteered, and all served with credit to themselves and to the state.

In the present World War which is an all-out war Iowa has to this date furnished $\mathbf{1 7 6 , 1 2 8}$ men and women for service. Of these, 71,034 were inducted and 105,084 have voluntarily enlisted. They are now serving in all parts of the world and units have been identified in Africa and in the Southwest Pacific and other points. From the reports we are now getting the Thirty-fourth Division, which includes the Iowa National Guard, has been engaged in the Tunisia fight in North Africa.

In all of this service Iowa has exceeded other states in its proportion of men and women in the service as to population. Hours could be put in extolling the bravery and relating the services that have been performed by the men and women from this state. It is sufficient to say that based upon the past history of Iowa as it is related to a military task that that task has been and will continue to be well and honorably performed.

Our present military task is not accomplished. The war has yet to be won. The president has named this an all-out war. The prime minister of Great Britain, Winston Churchill, has said: 
"This will be a war of blood, sweat and tears." There is no spot on the face of this globe that is not within the theater of operations. However, at this moment the ground forces of the warring nations are operating on foreign soil. Let us keep them there so that the worst ravages of the war will not come to our continent.

This is a war in which the services of men and women are needed not only for the armed forces but are also needed for the production of the materials of war and the foodstuff needed for our armies and our allies. We have seen that in each succeeding war the weapons used in battle have been so improved that it requires more men to support and supply those men who serve on the firing line. Because of this we are all engaged in this conflict.

This brings serious problems before us which must be solved both at the state level and at the federal level. The responsibility for conduct of the war is at the federal level. In this our responsibility as a state is to support the federal action. We should do this in such a manner that will not destroy our responsibility to the people of the state at the state level.

The American way is the way of liberty, justice and freedom. It is founded upon the constitution of the states and that of the United States. It is a dual form of government in which both participate. Each constitution defines those functions to be performed by each part of the whole government.

The American way as established by our forefathers is a way of peace and not as a way of war. War is the unusual thing contemplated in the organization of our government both state and national.

Of necessity when our country is called upon to defend itself against a common enemy certain of our peacetime activities and certain of our individual rights and privileges must be suspended until victory shall come. We must give full aid and support to the commander of our armed forces, the president of the United States. All that we have and all that we can do must be made available to be used against the common enemy. However, this can be done in a manner that when victory is won we will not have destroyed either part of our dual government or the American way of life.

Abram P. Staples, attorney general of the state of Virginia, as president of the American Association of Attorneys General of the United States in his address to this association expressed his view as to the functions of both state and federal government in both peace and war. With these views I agree. He said: "Let me, at the outset, make it clear that I neither advocate nor approve any action by the states during the time the nation is at war which would in any manner impede or obstruct the national government in its successful prosecution. On the contrary, it 
is my belief that unless our dual system of government can be made to function successfully in waging war it ought not to survive. And if it bogs down and cannot meet this supreme test we may be sure it will not survive."

Again he said: "It is essential that the state governments function efficiently at all times, but especially is this true in time of war. As said by President Roosevelt in his second inaugural address as governor of New York: 'When states become in different to their duties, the natural tendency is for the national go"ernment to grasp for more power.'"

Again he states: "But while I advocate this acquiesc, ce and cooperation in the free exercise of federal powers al opriate to the conduct of the war, at the same time I believe the attorneys general should openly and firmly emphasize the fact that the field of normal state powers yields to no other fede al power except that to wage war. We must ever be consciols of the fact that once the congress has exercised the war power in a normal state field, it will be reluctant to recognize when peace comes, that it must relinquish that field."

Again he states: "This tendency of congress to expand its own legislative sphere is not an unusual human trait. It is quite common."

Again he states: "If the regulatory powers of the state legislatures in local matters are to survive, it is absolutely essential that the states take planned, concerted action to prevent their destruction. This they have never done."

I also wish to quote from statements made by Elizabeth Brandeis, the daughter of the former justice of the supreme court of the United States, in an address published in the "Survey Graphic" in December, 1942, on the subject of "Centralization and Democracy." Among other things she said: "Most important of all, we must preserve the states because they are indispensable to a democratic system of government. We dare not transfer too many functions of government to Washington for fear of destroying the roots of democracy without which the whole tree will wither and die. This is far more than a figure of speech. For after all, what is a democratic system of government? Universal suffrage is not enough; not even when coupled with protection to civil and political liberty. Democratic government means government by the people, not just on election day, but all the year round. It requires real participation in government by private citizens."

In conclusion she states: "Democracy is not merely a form of government. It is a faith. In this country we believe profoundly that government by the people, though it will never be perfect, is better than any other form of government. But faith alone is not enough. To maintain democratic government, we must 
take care to preserve and develop arrangements by which private citizens can function effectively in the government process. That means above all, keeping as much government as possible 'back home' in the forty-eight states where private citizens live."

Since the beginning of our governments, both state and federal, there has not been a session of the legislative body of either that has not transferred from the people some of the rights and functions that $t^{\prime \prime}$ were reserved to them by both state and federal constitutions? As the prophet of old said: "Let us render unto Caesar tis things which are Caesar's; and unto God the things that ar"sc-sod's;" we say: "Let us render unto the federal governmentigfe things that are federal, and retain in the states the things thati are state."

About a decade ago when our state and nation was struck with the depression there was a tendency on the part of many states to abdicate to the federal government, to surrender their responsibilities for the welfare of their people to Uncle Sam. It seemed the easy way out. Too many were willing to sell their birthright for a mess of pottage. As stated in the Brandeis' address this was one of the first steps in the destruction of our dual form of government.

Let us remember that the welfare, happiness and prosperity of the people of our state is first our responsibility and is our first responsibility. Let us meet that responsibility and let us solve its problems. Let us guard the rights of our citizens against the encroachments of the federal government, and let us not in performing the military task now before us and in saving our country from our enemies who would destroy liberty, freedom and justice lose "The American Way."

\section{OUR Production Job}

PRESIDENT SCOTT: "An integral part of the gigantic task that lies before us is that of supplying our own Armed Forces around the world. But, not only that, is that of also aiding of all our allies. The next speaker this afternoon, a former speaker of the house of this assembly and at this time President of the Iowa Farm Bureau Federation, is one abundantly able to tell us something of the task of supplies, and I have the very great pleasure of presenting to you the Honorable Francis Johnson, who will speak on the subject of "Our Production Job'", 


\section{Mr. Johnson addressed the assembly as follows:}

This is an unusual privilege for one who used to be a member of this body, and I have to confess very humbly that I approach it with the same shaking of the knees and quivering of the voice that I did on the first day that I sat in the southeast corner of this Assembly Hall some twenty years ago. I feel also in a peculiar position, and yet it is one that $I$ think the farmers of Iowa have gotten used to in the last several years, in that I am preceded and followed by a member of the legal profession. Since World War I the farmers have found themselves in about this position. First, we go to the lawyers to draw the deed and the mortgage, and then a little later we go back to another lawyer during the foreclosure proceedings to help us get out of the predicament that the first lawyer got us into. And so this is not unfamiliar territory for me, a farmer, to be in on the present occasion. However, that is not addressing myself to this particular subject which was assigned to me today, that of "Our Production Job."

Colonel Stanley has very ably presented the job that lowa is faced with from the military standpoint, and Iowa is going to make a contribution comparable to all the other sister states in that respect in the winning of this war we are now faced with. But in so far as agriculture and the production of food is concerned Iowa has a very different, a very much larger job than do our sister agricultural states.

It is not any wonder, if you look at Iowa today, that the pioneers who came to this state in those early days should cast rather covetous eyes in this direction. But let us remember that those pioneers had not had the experience and did not know the unfathomable possibilities of this state agriculturally. When they pioneered this section Iowa was not as inviting those days as it is now. In fact it has been a real job to pioneer, for those men and women to go out and do the things that have been necessary to make Iowa as productive as it is today and to discover the fact that underneath the prairie grass that covered this state there lay at least twenty-five per cent of the most productive of the Grade $A$ land that all of the forty-eight states in these United States would eventually possess. That is Iowa's heritage today, and we have been able to bring it up to a point of almost maximum capacity production in so far as crops are concerned. Of course the weather favored us last year. In 1942 we exceeded all previous production records that even Iowa has been able to attain in the past.

Farmers are not sure that they are going to be able to repeat that showing in 1943. Yet they are expecting, I am sure, in 
spite of the handicaps that we are faced with, to do their very best to get that job done.

Just to give you some insight into the size of the job I would like to quote a few figures on what is being asked of us. In 1942 we were asked to produce $3,625,000$ hogs over 1941. We were asked to produce some 25 million dozen more eggs than we did in 1941, some 360 million pounds more milk than in 1941, and to slaughter some 213,000 more head of cattle, and to increase our acreage of soybeans, in order to increase this supply of fats and oils which are so necessary to win the war, by some 801,000 acres, without doing so at the expense of corn production and other necessary food and feed production. That job was not accomplished in every respect, and yet I have to say we did achieve some wonderful records.

But the thing we are interested in now is what are we going to be able to do in 1943. Everyone who is schooled in military tactics and support knows that an army cannot do as it did back in the days of the Civil War and the Revolutionary War and some of those which preceded that, and that is forage for its food as it conquered a country. We just don't do things that way any more. So it is up to the farmers of this nation to not only support that army of ours but to support the supporting civilian population and perhaps contribute in a degree, a large degree, to the support of the military forces and the civilians of our Allies, because without them probably we cannot win this war alone. I think that is generally conceded. And so we do have a real job facing us for 1943 .

I am just going to quote a few more figures of what is expected of us in that respect so that maybe we can get some idea of the size of the job. As far as corn is concerned we are going to be expected to produce more of that, because corn is one of the daily essentials to the production of livestock. These oil crops, such as flaxseed, soybeans, and so forth, we are again expected to make tremendous increases.

I wish you could have been with me last Monday when I interviewed the AAA committeeman from my own township in respect to my own farm, when I was asked to increase my own soybean crop by 200 per cent. Well, I thought I had been raising a respectable acreage up to that time. But that gives you some idea of the adjustments that farmers in this state are going to be asked or expected to make in order to meet some of these goals.

We are going to be expected to increase the farrowing of pigs this spring fifteen per cent, or 115 per cent of 1942, and next fall by twenty per cent, or 120 per cent of 1942 . I was just checking over some of these figures on total hog population and expected production in order to meet this job. before I left the office this forenoon, and I discovered a rather interesting thing, 
that if you come near achieving the goal in hogs for 1943 that has been set out for us that every man, woman and child who is recognized as a citizen, as a resident of this state, by the last census, will have to produce on an average of from nine to ten hogs next year-every citizen, man, woman and child, produce on an average of ten. When you divide that by the number of farmers in the state-first by the number of people living on farms, and then divide the number living on farms by the number of heads of families, you will realize that this state is going to produce a very sizeable amount of hogs if Iowa is to achieve this goal.

We have learned a lot in the last few years how to do this job out of the experience of these pioneers. I think it would be useless for me to spend my time here simply elaborating on the size of this job, if I did not say something about how it is going to be done. I have enough respect for not only the philosophy but the inherent natural ability of Iowa farmers to believe that this kind of a job, while it does have to be planned, it does have to be programmed, still the desire to do it is the only thing that will accomplish it, and therefore that it must be done on very much of a voluntary basis. with the proper kind of incentive and the proper furnishing of equipment and help in order to do those jobs. Therein lies at least two of the problems that confront the Iowa farmer in 1943-equipment and help.

And yet the Iowa farmer is not just going to be particular about the hours that he puts in nor too particular about the pay that he receives for getting that job done, because after all he is a part of his democracy, his state and his nation above all other things, and recognizes that he has as much responsibility as an individual to see that that job is done as anyone, whether that other individual be in the army or be in the supporting civilian population.

Some of the newspaper boys asked me before I came up this afternoon if I did not intend to talk about parity. Somehow or other they connect that phrase with the head of the farm organization as well as with the members. Well now, after all parity is not a thing that gets things done. Parity is simply a measure of whether the man is fairly compensated for doing the job after it is done. So I think parity as such has no particular connection with the subject which I am discussing here this afternoon. I know it is one that is being talked about in congress, it is being talked about by the farmers, it is being talked about by every group over the nation; but after all it is not the important thing, because after all parity prices may not be the kind of prices that will pay for the job of getting production in agriculture any more than good prices or poor prices are responsible for the lack of getting a production job done in industry or in the army. 
So let's not try to measure this thing in terms of that kind. After all price incentives probably have to be used, because it does cost something to do this job, and the greater you crowd your production beyond your capacity the higher the cost of production is bound to be. Industry has found that out. Agriculture knows it fully as well.

Now, Mr. Chairman, I think that I have probably said about as much, and consumed about as much time on this program on this particular subject, as I need to. May I simply say in closing that we are convinced that while this production job is going to be best achieved on a voluntary basis, that the farmers of this state and all of the other states who are going to be responsible for doing this job can better achieve it if, like the army, they organize their forces and put the men who are most able to do certain things in those places where they best fit. And that is our philosophy, and on that basis I am sure that agriculture in Iowa is going to render its full share of support towards the winning of this war and the preservation of this democracy.

\section{Fifty Legislative Sessions for Iowa}

PRESIDENT ScotT: "As we are centering our thought as a people upon the tremendous task that lies ahead of us, and that is well, perhaps as a state, we should pause in that contemplation for awhile this afternoon and look back in retrospect over the period of nearly one hundred years we have existed as a state and take some thought of the road over which we have traveled for nearly a century of time. The next speaker this afternoon is a man well known to all of us, a former Justice of the Supreme court of Iowa, and one who has played a very conspicuous role in the affairs of the state for a long period of years. I have great pleasure at this time to present to you Judge Frederic F. Faville, who will speak to the subject "Fifty Legislative Sessions for Iowa."

\section{Judge Faville spoke to the assembly as follows:}

I want to tell you a story that is a legend. More than a hundred years ago, more than four hundred years ago the legend says, a little band of aborigines floated down a magnificent river in their little canoes, and they stopped, climbed a high bank, looked over the beautiful prairie panorama with its carpet of many colored flowers, saw the murmuring forests and the laughing, 
rippling rills, and they cried out "Ioway, Ioway," which, being interpreted means "This is the land."

Now whether that legend be true or not the fact remains that of all the discovered land of the globe lying in one single tract or body, nowhere, not even in the fertile valley of the Nile, is there exceeded the fertility of the matchless soil of this state lying here in the heart of the continent and washed, guarded and girdled by the two great rivers of the Republic.

So we come here today at the high pinnacle of Iowa fortune to visit together for a few moments about this state and what it has been. It was originally a part of the Louisiana Purchase. Then it became a territory, annexed at one time to Missouri, at another to Michigan, at another one to Wisconsin, and for thirteen years it had no home at all. It was just left "out in the cold." But, as has been said to you this afternoon, about 1838 the territory was formed. I want to read to you, and I know that is excusable on this occasion, from my father's geography which he studied in a New England school in 1839. And this is what he learned then:

"If we glance an eye over this immense region, connected by navigable rivers-if we regard the fertility of the soil, the variety of productions, and if we combine those advantages offered by nature, with the moral energy of the free and active people who are spreading their increasing millions over its surface-what a brilliant prospect opens upon us through the darkness of future time! We see arts, science, industry, virtue and social happiness already increasing in that region beyond what the wildest fancy would have dared to hope, thirty or forty years ago."

Think of the prophecy. Today we can come here and see this very thing. As a foundation of what I want to say to you, I am going to make a request. When we adjourn this meeting and go into the rotunda, I want you to all pause long enough to look at Blashfield's matchless picture, for I think no matter how it may be interpreted, yet after all it portrays marvelously the essentials that founded this State. There is the old pioneer, marching along by the covered wagon with his gun, his sweetfaced wife holding her babe on her lap. But the significant thing is that four angels fly ahead of this pioneer coming into Iowa, and they are the angels, I think, that founded this great Statethe angels of industry, of education, of religious freedom and of law. Without them the fertility of our soil would be for naught. We are at the head of literacy in the United States. There are peoples that have learned to look to us because we have conceived the essential fundamentals of a new government.

I was asked to talk to you about the legislation that has happened in the last nearly one hundred years. The first state legislature in Iowa was elected on October 26, 1846. It convened November 
30,1846 , and you may be surprised to know that Iowa was not admitted to the Union, formally, until December 28, 1846. But the legislature was so anxious to get to work and get something done that they were not only elected but they actually convened before that state was admitted to the Union.

What kind of a land did they come into? There was not a conveyance in Iowa except the ox carts and the wagons, which were as old a means of transportation as Abraham when he tended his sheep on the Judean hills. The telegraph had just been invented. There was no telephone. No one was so insane as to think of the possibility of a radio or an automobile. There was not a safety match. The sewing machine was not invented until after that. No one dreamed of the possibility of a kodak. There was not a typewriter. Photography had just been discovered. No one was crazy enough to think of an airplane except "Darius Green and his flying machine." The idea of a submarine was impossible. The x-ray was never dreamed of. The reaper had just been invented. There were no paved roads. There was no barbed wire. There were no tractors. There was no rubber for teeth. There was no harvester. There was no electric light, and nobody had yet dreamed of the blessed thing, the Iowa primary.

One of the first important things that legislature had to do was to deal with the counties. They only had twenty-seven counties in Iowa at that time, and they were kept rather busy changing the names of the counties. May I tell you some of them? I wonder if you know what your own actually was. At that time we had a Bancroft county, or shortly afterwards. We had one called Buncombe. They say that they called it Buncombe because it was away up in northwestern Iowa, and it never would amount to anything. There was Belknap - a name we heard of in the Civil War. Did you know there was a Cook county in Iowa? Chicago stole it away from us. There was a Fox, a Grimes, a Kiskekosh. They had a bad time trying to spoil that beautiful name an Indian name-Kiskekosh. There was a Risely, a Slaughter, a Wahkaw, a Yell, and a Crocker, all of which they changed in due time.

One of the first things that legislature did was to adopt a school law and put Iowa on record in favor of the belief of Benjamin Franklin that an educated people never will go wrong permanently.

One of the very first acts they passed was one to authorize the governor to select all the salt springs in the state of Iowa. I have hunted diligently and failed to find where he ever made any report that he discovered any. Some politicians have made a discovery of salt creeks, but as far as salt springs were concerned, we had none. 
One of the very first things they did was to authorize the construction of canals, because there were no railroads, no roads, and the need was to get transportation of some kind.

But they were magnificent and generous. They gave the governor a salary of $\$ 2,000$, the secretary of state $\$ 1,000$, the auditor $\$ 1,200$, and the judges of the supreme court $\$ 2,000$ apiece.

Now since that time, from the first session of the legislature of Iowa to today there have been just 3,759 members of both Houses, just a little under 4,000 men, and a few women, members of the legislature that have helped make the laws for this great state. We have had, including the present one, twenty-nine governors. We have had seventy-one judges of the supreme court of Iowa. We have furnished twelve cabinet members from this state and three others who were born in Iowa who were appointed to the cabinet from other states. We have now furnished two justices of the supreme court of the United States; and we have also from Iowa given to the nation a man whom I regard as the greatest international statesman in the world, Herbert Hoover.

Colonel Stanley has told you about what Iowa has done in the Civil War and in the other wars. I want to tell you a story, if I may, that I had from the lips of the man who was a little stripling of a boy nineteen years of age during the Civil War. He carried the colors of his company, those colors now preserved in a case in this State House.

One spring morning his Iowa company with others was in a battle on the side of a mountain in Tennessee. The fog and the mist of the morning hung over them. They had orders to march up through the fog and mist into the sunshine and then halt and reform their lines. And this boy carried the colors, and they started up through the fog and mist, and they went above it into the bright sunlight, and the enemy, who was entrenched on the brow of the hill, began firing at them. These Iowa boys forgot all about the military command of the colonel. They were being shot at by the enemy. And this boy carried his flag on ahead. He hid behind a tree. He crouched behind a projecting rock. He got behind a big stump, but he went forward, and at last he made a run for it and planted his flag down in the very face of the enemy.

His captain shouted to him through the noise and the turmoil, "Sergeant, don't be rash. Bring that flag back to the men." And the little Irishman, standing with his flag, said, "Captain, the flag stays here. Bring your men up to the flag."

And he kept that flag there, that flag, and our flag of "equal rights for all and special privileges for none." We have planted them by the blood and the brains and the courage of the great 
people of Iowa. We have planted them under the eternal and everlasting stars of God Almighty, and no power on earth shall ever take them down.

I was going to say something to you about the productivity of Iowa, but Mr. Johnson has said it much more ably than I possibly could. I want to bring this thought to you. What we need in Iowa is a revival of these traditions and a firm resolve to continue the same things as the basic and fundamental principles of our civilization that these pioneers of America years ago laid down for this great State. Someone has very wisely said, "Of all that is good Iowa affords the best," and that is true. At this hour of a nation's crisis, what an inspiration it is that from these assembly halls, from this body of men, we can send out word to the Nation that in this great cause, we are true to the foundation principles upon which this State was established.

I know that you will join with me in your thoughts, if not with your lips, in the sentiment of the poet:

"Thou, too, sail on, O ship of State! Sail on, O Union, strong and great!

Humanity with all its fears,

With all its hopes of future years, Is hanging breathless on thy fate!

We know what Master laid thy keel, What Workmen wrought thy ribs of steel,

Who made each mast, and sail, and rope,

What anvils rang, what hammers beat,

In what a forge and what a heat,

Were shaped the anchors of thy hope!

Fear not each sudden sound and shock,

'Tis of the wave and not the rock;

'Tis but the flapping of the sail,

And not a rent made by the gale.

In spite of rock and tempest's roar,

In spite of false lights on the shore,

Sail on, nor fear to breast the sea!

Our hearts, our hopes, are all with thee,

Our hearts, our hopes, our prayers, our tears,

Our faith triumphant o'er our fears,

Are all with thee-are all with thee!"

God bless America.

PRESIDENT SCOTT: This concludes the formal program for the afternoon. Speaking for the Pioneer Lawmakers' Association, we congratulate the Fiftieth General Assembly upon the work which you have done to this date, 
and we.indulge in the hope and have the conviction that when you have finished your duties and have returned to your homes that you shall have your reward in the consciousness of a work well done. We thank you for all the courtesies that you have extended to us this day, and we bid you farewell until the next session two years hence.

On motion by Representative Te Paske of Sioux, the Joint Convention was dissolved.

Pioneer Association OfFicers 1943-45

The new officers of the Iowa Pioneer Lawmakers Association for the 1943-1945 period as selected are:

President. Israel A. Smith, Independence, Mo.

Vice President John M. Rankin, Keokuk Secretary Emory H. English, Des Moines

\section{District Vice Presidents}

First J. M. Brockway, Muscatine

Second C. F. Clark, Cedar Rapids

Third

Fourth

Fifth

Sixth Carl W. Reed, Cresco

Seventh

Eighth Frank J. Shane, Ottumwa Ed. M. Smith, Winterset W. W. Goodykoontz, Boone Geo. W. VanCamp, Greenfield C. E. Narey, Spirit Lake

EXecutive Committee

Israel A. Smith John M. Rankin Independence, Mo.

Emory H. English Geo. M. Titus. Keokuk

H. S. VanAlstine

Ray P. Scott Des Moines Fred H. Hunter Muscatine Gilmore City Marshalltown Des Moines

\section{REGRETS FROM ABSENT MEMBERS}

Restrictions upon travel, pressure from unusual conditions incident to the war effort, illness and many other valid reasons expressed in letters replying to notice of the date of the meeting reached the association secretary from members unable to attend, indicating both interest 
in the sessions and affection for those attending to whom greetings are extended, some of which are quoted:

C. A. Kennedy, $(30 \mathrm{R})$, Montrose: "Because of ill health that has held me at home all winter will not be able to attend, much as I would desire to. Extend personal regards."

William Carden, (29 R), Winfield: "Sorry I cannot be with you, but March 1st business prevents. It would have been a real pleasure to have been with my former friends of the legislature. Best wishes to all those present for a happy reunion."

Karl M. LeCompte, (37 S), Washington, D. C.: "The invitation brought to me many happy memories. I have intended for many years to attend one of these gatherings. It doesn't seem very long to me when $I$ was in the legislature and the Pioneers met with us. I thought they looked like old, old men-but probably the majority were not any older than I am now. Twenty years bring about many changes."

Geo. A. Wilson, (42 S), Washington, D. C.: "I regret exceedingly that it will not be possible for me to attend. I would like very much to see my many good friends who will be there."

Claude R. Porter, (26 R), Washington, D. C.: "Regret that work on the Commission, together with conditions of travel make it impossible for me to attend, although if I am spared, I do want to attend an early meeting. I am wondering if you have any members antedating my service. I was a member of the Twentysixth General Assembly which convened in January 1896. I was the youngest member then and regret to say now that I am considerably older."

Guy M. Gillette, (35 S), Washington, D. C.: "While my good wishes will be with the gathering, my presence there is out of the question, much to my regrets."

H. M. Havner, (Atty. Gen. '17), Des Moines: "A district court hearing at Newton will prevent my being in attendance. I am sure it will be an interesting program, and in addition there is the pleasure of meeting one's old friends."

Frank A. O'Connor, (33 R), Dubuque: "Absence of gas and other appointments makes it impossible for me to be present. Would enjoy seeing many of the old friends."

Justin Barry, (35 R), Cherokee: "Impossible for me to attend. Should enjoy greatly the opportunity to meet many old-time friends again."

E. K. Winne, (29 S), Laurens: "Planned for sure to be present this year but shortage of help in our bank has made it impossible."

W. F. Craig, (35 R), Champaign, Ill.: "Names on the program 
bring back pleasant memories of days gone by, and I thoroughly appreciate that I am eligible for membership."

B. W. Newberry, (30 S), Strawberry Point: "I would surely like to attend, but will be unable to do so. In looking over the list of the present officers of the association I find that I served with nearly all of them-all good worthy men. It is a great pleasure to have been associated with them. I extend greetings to all."

L. W. Powers, (38 R), Omaha, Neb.: "Could not arrange to attend this time. I hope to attend the next meeting."

Thos. A. Way, (28R), Glendale, Cal.: "Some kind friend told you how to reach me by mail. I am grateful indeed to receive the invitation. Many of the names on the program are well known to me. I am pleased to send my regards."

Burton E. Sweet, (28R), Waverly: "I would have been a great pleasure to me to be able to meet with my many old friends."

Wm. G. Kerr, (28 R), Azusa, Cal.: "The Pioneer Lawmakers of Iowa have done their part man for man in making Iowa what it is today. All deserve praise. Many thanks for favors received."

John H. Darrah, (31 R), Kansas City: "Absence in person cannot prevent me from being present in spirit-nor can it impede or obstruct the processes of imagination, or the powers of memory from functioning. I note among the official personnel the names of many intimate and highly esteemed old friends. To those in particular I send personal greetings of remembrance, and to all members present I extend my warm and sincere felicitations for a happy reunion and success of the meeting."

John T. Moffit, (28 S), Tipton: "Sorry I cannot attend."

Rube McFerren, (36 R), Webster City: "Notice of the meeting brings back old memories. It has been twenty-five years since I was in the House. Then I thought I would never grow old. I have changed my mind, although I am feeling fine. Aside from George Groves and Frank Lund, of Webster City, I do not recall any others from this county eligible to membership."

Gardner Cowles, (28 R), Des Moines: "It so happens that I am due to meet an engagement out of the city on the date of the Pioneers meeting, and I cannot be with you."

J. O. Kasa, (24 R), Wallingford: "If H. T. Saberson, now at Des Moines, still is living, we two are the only members yet living, as far as I know, from the Twenty-fourth General Assembly, 1892. I will be 84 years young on June 8 next. I was a youngt chap when down there fifty-one years ago, and still very active. I represented three counties in my district. Greetings to my friends."

L. R. Bingham, (35 R), Los Angeles: "Sorry, but too many miles 
intervene. A heart-warming and satisfactory time for all more fortunately situated."

Lyman L. Bybee, (34 R), Knoxville: "Regret that it will not be possible for me to be present."

H. A. Darting, (39 S), Glenwood: "Regret much that I cannot attend our meeting this time."

Harry C. White, (34 R), Vinton: "For business reasons I will not be able to be present. I am very sorry."

Fred Larrabee, (33 S), Clermont: "I cannot attend the Iowa Lawmakers Association meeting this year."

C. F. Clark, (38 R), Cedar Rapids: "Regret very much that I will not be able to attend this year."

Lee O. Wolfe, (39 R), Titonka: "I regret that it is impossible for me to attend the meeting."

J. E. Jamison, (35 R), Burlington: "Do not expect me at the meeting. Sorry to be absent."

R. G. Clark, (27 R), Des Moines: "Sorry to miss this year's meeting. You have a fine program. My family thinks it would be unwise for me to attempt the trip during the cold weather and I guess they are right."

W. W. Goodykoontz, (33 R), Boone: "Hardly think it possible to be with you this year. Sorry to miss out and hope you have a good meeting in every way."

Joe R. Frailey, (36 S), Fort Madison: "Tried to arrange my matters so that $I$ could be in attendance at the Pioneer Lawmakers meeting. However, I could not. Very much wanted to attend this reunion, but it was impossible."

Geo. E. Roberts (St. Ptr. 83), New York City: "Thank you for the notice and invitation. I was elected State Printer by the Nineteenth G. A., but my term of service did not begin until after the new capitol was occupied. I remember John A. Storey from Adair county. I always thought highly of him. I knew the VanAlstine family, northwest from Fort Dodge, from early days-a fine family. I knew Charles Aldrich, a highly intelligent man. He was in the Nineteenth G. A. and voted for me. He did a great service to the state. The Historical Department is a real monument to him and he foresaw that it would be. Of course I knew B. F. Gue, Governor Carroll and R. G. Clark, and practically all of the list of past presidents of the Pioneer Lawmakers down to and including Emory English, excepting John T. Clarkson, whom I knew of. I recall B. F. Clayton, and have him as from Pottawattamie." 
Copyright of Annals of Iowa is the property of State of Iowa, by \& through the State Historical Society of Iowa and its content may not be copied or emailed to multiple sites or posted to a listserv without the copyright holder's express written permission. However, users may print, download, or email articles for individual use. 